\title{
Immunological programming by breast milk creates an anti-inflammatory cytokine milieu in breast-fed infants compared to formula-fed infants
}

\author{
Essi Kainonen*, Samuli Rautava and Erika Isolauri \\ Department of Paediatrics, Turku University Hospital, Kiinamyllynkatu 4-8, Turku 20520, Finland \\ (Submitted 26 September 2011 - Final revision received 10 May 2012 - Accepted 28 June 2012 - First published online 30 October 2012)
}

\begin{abstract}
Breast milk provides important maturational stimuli to an infant's developing immune system. However, data concerning the role of breast-feeding in reducing the risk of allergic disease remain contradictory. Previous studies have centred on comparative analyses of breast milk and formula compositions. We chose a slightly different angle, whereby we focused on the effects of the chosen diet on the infant himself, comparing the immune development of formula-fed and breast-fed children. The objective of the present study was to determine how the mode of feeding affects infant immunology. Altogether, eighteen formula-fed infants with limited breast-feeding for $<3$ months and twenty-nine infants who were exclusively breast-fed for $>3$ months were included in the study. Concentrations of interferon $\gamma$, TNF- $\alpha$ IL-10, IL-5, IL-4 and IL-2 were measured simultaneously from the same serum sample through use of a multiplexed flow cytometric assay at the ages of $1,3,6$ and 12 months. Transforming growth factor $\beta 2$ (TGF- $\beta 2$ ) was measured using ELISA at the same time points. Serum TNF- $\alpha$ and IL-2 concentrations were significantly higher in formula-fed than in breast-fed infants during the first year of life (ANOVA, $P=0 \cdot 002$ ). The serum concentrations of TGF- $\beta$ were significantly lower in formula-fed than in breast-fed infants throughout the first year of life (ANOVA, $P \leq 0 \cdot 0001$ ). Exclusive breast-feeding promotes an anti-inflammatory cytokine milieu, which is maintained throughout infancy. Such an immunological environment limits hyper-responsiveness and promotes tolerisation, possibly prohibiting the onset of allergic disease.
\end{abstract}

Key words: Infants: Breast milk: Immunology: Allergy: Transforming growth factor $\beta$ : Tolerisation: Cytokines

Breast milk has undergone hundreds of thousands of years of product development during the evolution of our species. It can, with confidence, be claimed to be the ideal form of nutrition for the human infant during the first months of life and the ideal supplement to solid nutrition during the infant's first years. In addition to providing developmentally appropriate nutrition, breast milk contains a multitude of immunologically active components. In the same manner that breast milk has evolved to fit the needs of our infants, it can be assumed that our infants have evolved to develop in the presence of breast milk. Despite being well-equipped for extra-uterine life at the time of birth, the newborn infant also has several shortcomings, and the most profound are those faced by the immature immune system. The infant undergoes a transition from the sterile environment experienced in utero to one that is filled with microbes, and he must also begin to feed. It is, thus, essential that his immune system learns to differentiate between hostile and innocuous antigens.

Breast milk may help infants in these essential adaptations. It provides infants with direct anti-pathogenic effects via maternal microbe-specific Ig and various other antimicrobial substances $^{(1-3)}$, and has an extensively documented ability to ward off infective disease, such as infantile diarrhoea, in developing countries ${ }^{(4-6)}$, but also common causes of pathogen-related infant morbidity in western settings ${ }^{(7-10)}$. There is also an impressive amount of data to suggest that its recipients are protected from common disruptions of the immune system such as type 1 diabetes ${ }^{(11)}$, inflammatory bowel disease ${ }^{(12)}$, coeliac disease ${ }^{(13)}$ and atopic diseases, including allergies and asthma ${ }^{(10,14-21)}$. Breast-feeding promotes gut colonisation with beneficial bifidobacteria in infants $^{(1,22-24)}$, and this finding may be linked with many of the advantages associated with breast-feeding.

Nevertheless, results on the potency of breast milk in reducing the risk of atopic disease remain unclear and contradictory, with evidence for both decreased ${ }^{(14-21,25)}$ and increased $^{(26-31)}$ risk of atopic disease in breast-fed children, and no proven dose-response pattern. The effects of breastfeeding, or the lack of it, on infant immune physiology have thus remained elusive.

In the present study, we determined blood plasma concentrations of key cytokines and circulatory antibody-secreting cells in exclusively breast-fed infants, and compared them with

Abbreviation: TGF- $\beta 2$, transforming growth factor $\beta 2$.

*Corresponding author: E. Kainonen, fax +3582323 1460, email esskai@utu.fi 
those of infants who had experienced early termination of breast-feeding and had been primarily fed with formula. The present study aimed to shed light on whether differing immune physiology is evident in breast-fed and formula-fed infants.

\section{Materials and methods \\ Design}

The infants in the study were selected from a prospective study ( $n$ 98) that had followed them up from birth to the age of 12 months. The majority of the participants were genetically at high risk for atopy, with the mother or other first-degree relatives with atopic disease. This family history was self-reported. A case-control design was chosen, as it is not feasible to conduct a randomised study on breast-feeding. The inclusion criteria for the formula-fed group were the complete cessation of breast-feeding before 3 months of age and consequent exclusive formula feeding at that age. Infants who were exclusively breast-fed at 3 months of age were chosen as controls. Infants with chronic disease were excluded from the study. Altogether, eighteen formula-fed and twenty-nine exclusively breast-fed infants fulfilled the criteria of the study. The present study was conducted according to the guidelines laid down in the Declaration of Helsinki, and all procedures involving human patients were approved by the Turku University Central Hospital Ethics Committee. Written informed consent was obtained from all patients.

\section{Determining plasma cytokine concentrations using}

\section{cytometric bead assays and ELISA}

Venous blood samples were drawn, heparinised and stored at $-80^{\circ} \mathrm{C}$ for later analysis at the ages of $1,3,6$ and 12 months. The samples of formula-fed infants were drawn between September 2000 and February 2002 and the samples of breast-fed infants between May 2000 and August 2002 in almost parallel follow-up periods. The concentrations of the cytokines interferon $\gamma$, TNF- $\alpha$, IL-10, IL-5, IL-4 and IL-2 were measured simultaneously from the same blood plasma sample through use of a multiplexed bead-based flow cytometric assay between August and September 2003, and all samples had been stored at the same facility in similar conditions. A commercial Human Th1/Th2 Cytokine Kit, BD Cytometric Bead Array, a FACSCalibur flow cytometer and BD CBA Software (BD Immunocytometry Systems and BD Biosciences Pharmingen) were used for the analysis according to the manufacturer's specifications. The detection limits for these cytokines according to the manufacturer were $7 \cdot 1 \mathrm{pg} / \mathrm{ml}$ for interferon $\gamma, 2.6 \mathrm{pg} / \mathrm{ml}$ for IL-2, $2.6 \mathrm{pg} / \mathrm{ml}$ for IL-4, $2 \cdot 4 \mathrm{pg} / \mathrm{ml}$ for IL-5, $2 \cdot 8 \mathrm{pg} / \mathrm{ml}$ for IL-10 and $2 \cdot 8 \mathrm{pg} / \mathrm{ml}$ for TNF- $\alpha$.

Cytometric bead assay analyses were carried out simultaneously during August and September 2003. The plasma concentrations of transforming growth factor $\beta 2$ (TGF- $\beta 2$ ) were measured in duplicate using commercial sandwich ELISA specific for the molecule (R\&D Systems). Activation of latent TGF- $\beta 2$ and all determinations were carried out according to the manufacturer's instructions.

\section{Determining the number of Ig-secreting cells}

The total number of Ig-secreting cells and the number of cells producing antibodies directed specifically against the cows' milk allergen, casein, were measured using the enzyme-linked immunospot assay, as detailed in previous work (Isolauri et al), from blood samples obtained at the ages of 3, 6 and 12 months. On the day of sample collection, peripheral blood mononuclear cells were isolated using FicollPaque gradient centrifugation. Isolated cells were washed three times in Hanks balanced salt solution and suspended in Roswell Park Memorial Institute 1640 medium containing

Table 1. Clinical characteristics of participants

(Mean values and ranges; number of participants and percentages)

\begin{tabular}{|c|c|c|c|c|c|}
\hline & \multicolumn{2}{|c|}{ Formula-fed $(n 18)$} & \multicolumn{2}{|c|}{ Breast-fed ( $n$ 29) } & \multirow[b]{2}{*}{$P$} \\
\hline & Mean & Range & Mean & Range & \\
\hline Boys & & & & & 0.53 \\
\hline$n$ & \multicolumn{2}{|r|}{7} & \multicolumn{2}{|r|}{14} & \\
\hline$\%$ & \multicolumn{2}{|r|}{38} & \multicolumn{2}{|r|}{48} & \\
\hline Gestational age (weeks) & $40 \cdot 1$ & $36 \cdot 7-42 \cdot 3$ & $39 \cdot 2$ & $37 \cdot 0-42 \cdot 0$ & 0.051 \\
\hline Birth weight $(\mathrm{g})$ & 3485 & $2580-4260$ & 3544 & $2730-4890$ & 0.68 \\
\hline Caesarian section & & & & & 0.12 \\
\hline$n$ & \multicolumn{2}{|r|}{5} & \multicolumn{2}{|r|}{3} & \\
\hline$\%$ & \multicolumn{2}{|r|}{28} & \multicolumn{2}{|r|}{10} & \\
\hline Duration of exclusive breast feeding (months) & 0.5 & $0.0-1.5$ & $4 \cdot 1$ & $3 \cdot 0-6 \cdot 0$ & $<0.0001$ \\
\hline Overall duration of breast feeding (months) & $1 \cdot 4$ & $0 \cdot 0-2 \cdot 8$ & 9.9 & $4 \cdot 2-12 \cdot 0$ & $<0.0001$ \\
\hline \multicolumn{6}{|l|}{ Family history of $A D$} \\
\hline \multicolumn{6}{|l|}{ First-degree relative $A D$} \\
\hline$n$ & \multicolumn{2}{|r|}{14} & \multirow{2}{*}{\multicolumn{2}{|c|}{29}} & 0.04 \\
\hline$\%$ & \multicolumn{2}{|r|}{77} & & & \\
\hline \multicolumn{4}{|l|}{ Maternal AD } & & \\
\hline$n$ & \multicolumn{2}{|r|}{12} & \multirow{2}{*}{\multicolumn{2}{|c|}{$\begin{array}{c}29 \\
100\end{array}$}} & 0.009 \\
\hline$\%$ & \multicolumn{2}{|r|}{67} & & & \\
\hline
\end{tabular}

$A D$, atopic disease. 
Table 2. Serum cytokine concentrations in formula-fed and breast-fed infants (Geometric means and 95\% confidence intervals)

\begin{tabular}{|c|c|c|c|c|c|c|c|c|c|c|c|c|c|}
\hline & \multirow[b]{3}{*}{$\begin{array}{c}\text { Age } \\
\text { (months) }\end{array}$} & \multicolumn{4}{|c|}{ All participants } & \multirow{3}{*}{$\begin{array}{c}P(\text { ANOVA } \\
\text { for } \\
\text { repeated } \\
\text { measures) }\end{array}$} & \multirow[b]{3}{*}{$P$} & \multicolumn{4}{|c|}{ Only atopic mothers } & \multirow{3}{*}{$\begin{array}{c}P \text { (ANOVA } \\
\text { for } \\
\text { repeated } \\
\text { measures) }\end{array}$} & \multirow[b]{3}{*}{$P$} \\
\hline & & \multicolumn{2}{|c|}{ Formula-fed ( $n$ 18) } & \multicolumn{2}{|c|}{ Breast-fed ( $n$ 29) } & & & \multicolumn{2}{|c|}{ Formula-fed ( $n$ 12) } & \multicolumn{2}{|c|}{ Breast-fed ( $n$ 29) } & & \\
\hline & & $\begin{array}{c}\text { Geometric } \\
\text { mean }\end{array}$ & $95 \% \mathrm{Cl}$ & $\begin{array}{c}\text { Geometric } \\
\text { mean }\end{array}$ & $95 \% \mathrm{Cl}$ & & & $\begin{array}{l}\text { Geometric } \\
\text { mean }\end{array}$ & $95 \% \mathrm{Cl}$ & $\begin{array}{l}\text { Geometric } \\
\text { mean }\end{array}$ & $95 \% \mathrm{Cl}$ & & \\
\hline \multirow{4}{*}{$\begin{array}{l}\text { Serum TGF- } \beta 2 \\
\quad(\mathrm{pg} / \mathrm{ml})\end{array}$} & 1 & 89 & 68,116 & 300 & 325,356 & \multirow[t]{4}{*}{$<0.0001$} & $<0.0001$ & 84 & 61,117 & 340 & 325,356 & \multirow[t]{4}{*}{$<0.0001$} & $<0.0001$ \\
\hline & 3 & 82 & 53,129 & 406 & 376,438 & & $<0.0001$ & 98 & 57,169 & 406 & 376,438 & & $<0.0001$ \\
\hline & 6 & 150 & 84,268 & 285 & 216,376 & & 0.039 & 132 & 63,277 & 285 & 216,376 & & 0.029 \\
\hline & 12 & 35 & 18,71 & 362 & 280,469 & & $<0.0001$ & 45 & 20,104 & 362 & 280,469 & & $<0.0001$ \\
\hline \multirow{4}{*}{$\begin{array}{l}\text { Serum IFN- } \gamma \\
(\mathrm{pg} / \mathrm{ml})\end{array}$} & 1 & $25 \cdot 7$ & $7 \cdot 8,82 \cdot 3$ & 26 & $16 \cdot 1,41 \cdot 8$ & \multirow[t]{4}{*}{$0 \cdot 10$} & & 11.9 & $3 \cdot 0,45 \cdot 9$ & 26 & $16 \cdot 1,41 \cdot 8$ & \multirow[t]{4}{*}{0.36} & \\
\hline & 3 & $40 \cdot 7$ & $14 \cdot 9,111$ & 12 & $9 \cdot 6,15 \cdot 1$ & & & $43 \cdot 6$ & $12 \cdot 1,157 \cdot 7$ & 12 & $9 \cdot 6,15 \cdot 1$ & & \\
\hline & 6 & 71.7 & $27 \cdot 6,187$ & $15 \cdot 4$ & $9 \cdot 6,24.5$ & & & $59 \cdot 3$ & $19 \cdot 4,181 \cdot 6$ & $15 \cdot 4$ & $9 \cdot 6,24 \cdot 5$ & & \\
\hline & 12 & $27 \cdot 8$ & $13 \cdot 2,58 \cdot 2$ & $17 \cdot 5$ & $12 \cdot 5,24 \cdot 4$ & & & 20 & $9 \cdot 7,41 \cdot 4$ & 17.5 & $12 \cdot 5,24 \cdot 4$ & & \\
\hline \multirow{4}{*}{$\begin{array}{l}\text { Serum TNF- } \alpha \\
\quad(\mathrm{pg} / \mathrm{ml})\end{array}$} & 1 & 1.6 & $1 \cdot 1,2 \cdot 2$ & $1 \cdot 1$ & $0.8,1.3$ & \multirow[t]{4}{*}{0.002} & 0.039 & 1.6 & $1 \cdot 0,2 \cdot 3$ & 1 & $0.8,1.3$ & \multirow[t]{4}{*}{0.005} & 0.076 \\
\hline & 3 & 1.5 & $1 \cdot 0,2 \cdot 3$ & 1 & $0 \cdot 7,1 \cdot 2$ & & 0.1 & 1.6 & $0 \cdot 9,2 \cdot 8$ & 1 & $0 \cdot 7,1 \cdot 2$ & & 0.094 \\
\hline & 6 & $3 \cdot 1$ & $1 \cdot 4,6 \cdot 4$ & 1 & $0.8,1 \cdot 2$ & & 0.001 & 3 & $1 \cdot 2,7 \cdot 1$ & 1 & $0.8,1 \cdot 2$ & & 0.002 \\
\hline & 12 & $2 \cdot 8$ & $2 \cdot 0,4.5$ & 1 & $0.8,1.3$ & & 0.0001 & $2 \cdot 6$ & $1.9,3.6$ & 1 & $0.8,1.3$ & & $<0.0001$ \\
\hline \multirow{4}{*}{$\begin{array}{l}\text { Serum IL-10 } \\
\quad(\mathrm{pg} / \mathrm{ml})\end{array}$} & 1 & $6 \cdot 5$ & $5 \cdot 8,7 \cdot 2$ & $5 \cdot 7$ & $4 \cdot 9,6 \cdot 6$ & \multirow[t]{4}{*}{0.05} & & 6 & $5 \cdot 2,6 \cdot 9$ & $5 \cdot 7$ & $4 \cdot 9,6 \cdot 6$ & \multirow[t]{4}{*}{0.12} & \\
\hline & 3 & $8 \cdot 3$ & $5 \cdot 8,11 \cdot 8$ & 6.5 & $5 \cdot 8,7 \cdot 3$ & & & $8 \cdot 6$ & $5 \cdot 2,14 \cdot 1$ & 6.5 & $5 \cdot 8,7 \cdot 3$ & & \\
\hline & 6 & $21 \cdot 6$ & $9 \cdot 2,50 \cdot 3$ & $6 \cdot 3$ & $4.9,8 \cdot 1$ & & & $19 \cdot 9$ & $7 \cdot 3,54.5$ & $6 \cdot 3$ & $4.9,8 \cdot 1$ & & \\
\hline & 12 & 11 & $7 \cdot 2,16 \cdot 9$ & 8 & $7 \cdot 0,9 \cdot 1$ & & & 8.4 & $6 \cdot 3,11 \cdot 1$ & 8 & $7 \cdot 0,9 \cdot 1$ & & \\
\hline \multirow{4}{*}{$\begin{array}{l}\text { Serum IL-5 } \\
\quad(\mathrm{pg} / \mathrm{ml})\end{array}$} & 1 & 2.5 & $1 \cdot 9,3 \cdot 2$ & $2 \cdot 6$ & $2 \cdot 1,3 \cdot 3$ & \multirow[t]{4}{*}{0.84} & & $2 \cdot 3$ & $1 \cdot 6,3 \cdot 3$ & $2 \cdot 6$ & $2 \cdot 1,3 \cdot 3$ & \multirow[t]{4}{*}{0.44} & \\
\hline & 3 & $2 \cdot 1$ & $1 \cdot 5,2 \cdot 8$ & 2 & $1 \cdot 7,2 \cdot 4$ & & & $2 \cdot 3$ & $1.5,3.5$ & 2 & $1 \cdot 7,2 \cdot 4$ & & \\
\hline & 6 & 4.9 & $2 \cdot 6,9 \cdot 1$ & $3 \cdot 2$ & $2 \cdot 5,4 \cdot 0$ & & & $4 \cdot 1$ & $2 \cdot 1,7 \cdot 8$ & $3 \cdot 2$ & $2 \cdot 5,4 \cdot 0$ & & \\
\hline & 12 & 3 & $2 \cdot 0,4 \cdot 5$ & $2 \cdot 6$ & $2 \cdot 1,3 \cdot 2$ & & & $2 \cdot 3$ & $1.6,3 \cdot 1$ & $2 \cdot 6$ & $2 \cdot 1,3 \cdot 2$ & & \\
\hline \multirow{4}{*}{$\begin{array}{c}\text { Serum IL-4 } \\
\quad(\mathrm{pg} / \mathrm{ml})\end{array}$} & 1 & 4.8 & $2 \cdot 4,9 \cdot 8$ & $2 \cdot 1$ & $1.7,2.5$ & 0.28 & & 4.5 & $1.9,10.5$ & $2 \cdot 1$ & $1 \cdot 7,2.5$ & 0.067 & \\
\hline & 3 & 2.5 & $1 \cdot 5,4 \cdot 3$ & $2 \cdot 1$ & $1.6,2.9$ & & & $3 \cdot 1$ & $1 \cdot 7,5 \cdot 8$ & $2 \cdot 1$ & $1.6,2.9$ & & \\
\hline & 6 & $5 \cdot 1$ & $2 \cdot 5,10 \cdot 2$ & 2.5 & $1.9,3.2$ & & & 4.8 & $1 \cdot 7,13 \cdot 3$ & 2.5 & $1.9,3.2$ & & \\
\hline & 12 & 3.7 & $2 \cdot 2,60 \cdot 1$ & $2 \cdot 8$ & $2 \cdot 3,3 \cdot 5$ & & & $2 \cdot 6$ & $1 \cdot 5,4 \cdot 6$ & $2 \cdot 8$ & $2 \cdot 5,3.5$ & & \\
\hline Serum IL-2 & 1 & $2 \cdot 2$ & $1 \cdot 5,3 \cdot 2$ & 1 & $0 \cdot 8,1 \cdot 2$ & 0.0001 & 0.0003 & $2 \cdot 6$ & $1 \cdot 7,4 \cdot 0$ & 1 & $0 \cdot 8,1 \cdot 2$ & 0.0001 & 0.0002 \\
\hline (pg/ml) & 3 & 3 & $1.9,4.7$ & $1 \cdot 1$ & $0.8,1.4$ & & 0.001 & 3.5 & $1.8,6.5$ & $1 \cdot 1$ & $0.8,1.4$ & & 0.002 \\
\hline & 6 & 4.4 & $1.9,9.7$ & 1 & $0.7,1.1$ & & $<0.0001$ & $3 \cdot 6$ & $1 \cdot 5,8 \cdot 8$ & 1 & $0.7,1 \cdot 1$ & & 0.0003 \\
\hline & 12 & $2 \cdot 6$ & $1 \cdot 6,4 \cdot 3$ & 1.3 & $1 \cdot 0,1 \cdot 7$ & & 0.014 & 2 & $1 \cdot 2,3 \cdot 3$ & 1.3 & $1 \cdot 0,1 \cdot 7$ & & 0.12 \\
\hline
\end{tabular}

TGF- $\beta 2$, transforming growth factor $\beta 2$; IFN- $\gamma$, interferon $\gamma$. 
$10 \%$ fetal calf serum and adjusted to a concentration of $1-2 \times 10^{6}$ cells $/ \mathrm{ml}$.

To determine the total number of Ig-secreting cells, the wells were coated for $2 \mathrm{~h}$ at $37^{\circ} \mathrm{C}$ with rabbit anti-human IgA, IgG and IgM (Dako A/S) diluted in the ratio 1:100 in PBS ( $\mathrm{pH} \mathrm{7.4),} \mathrm{and} \mathrm{to} \mathrm{detect} \mathrm{the} \mathrm{number} \mathrm{of} \mathrm{cells} \mathrm{secreting}$ casein-specific antibodies, the coating was performed with $\beta$-casein $(20 \mu \mathrm{g} / \mathrm{ml}$; Sigma Chemical Company). Uncoated binding sites were blocked with $1 \%$ bovine serum albumin (Boehringer Mannheim) in PBS ( $\mathrm{pH} \mathrm{7.4)} \mathrm{for} 30 \mathrm{~min}$ at $37^{\circ} \mathrm{C}$. After washing, the lymphocyte suspension was incubated on antigen-coated flat-bottomed ninety-six-well microtitre plates (Immunoplate RI, A/S Nunc) at $37^{\circ} \mathrm{C}$ for $2 \mathrm{~h}$. The detection of antibodies secreted during that time was performed with alkaline phosphatase-conjugated goat antiserum to human IgA, IgG and IgM (Sigma Chemical Company), diluted in 1\% bovine serum albumin-PBS ( $\mathrm{pH} 7.4)$ and incubated overnight at room temperature, followed by a substrate agarose overlay and observation of the coloured spots.

\section{Statistical evaluation}

The clinical data are described as means with ranges. The differences in clinical characteristics between the study groups were assessed using Student's $t$ test and the $\chi^{2}$ test. The results are expressed as geometric means with $95 \% \mathrm{CI}$. The differences between serum cytokine concentrations in the breast-fed and formula-fed infants during the course of the follow-up were assessed using ANOVA for repeated measures after logarithmic transformation. If the ANOVA suggested a difference between groups, further analyses at each time point were conducted using Student's $t$ test after logarithmic transformation. A $P$ value of less than 0.05 was considered statistically significant.

\section{Results}

\section{Clinical data}

The clinical characteristics of the participants are shown in Table 1 . The study groups were comparable with regard to gestational age, sex, birth weight and the mode of delivery, while differing on the mode of feeding according to the study design. Due to the design of the original prospective cohort, the family history of atopy differed between the formula-fed and breast-fed groups. A total of fourteen of the eighteen (77\%) formula-fed infants had a first-degree relative with atopic disease compared to all of the twenty-nine (100\%) breast-fed infants $(P=0.04)$. A total of twelve of the eighteen (67\%) formula-fed infants had a mother with clinical atopic disease compared to all of the twenty-nine (100\%) in the breast-fed group $(P=0.009)$. The groups are, thus, significantly different regarding family history of atopy. However, the cytokine results observed persist and remain significant even when only the participants with atopic mothers are evaluated (i.e. when the six formula-fed participants without an atopic mother are excluded from the evaluation), suggesting that the differences witnessed in cytokine concentrations are not due to the differences in family history of atopy (Table 2).

\section{Differing plasma cytokine concentrations in formula-fed and breast-fed infants}

ANOVA for repeated measures showed a significant difference in TNF- $\alpha$ concentrations $(P=0 \cdot 0019)$, with elevated serum TNF- $\alpha$ concentrations in formula-fed infants compared to their breast-fed counterparts (Fig. 1). Serum IL-2 concentrations $(P=0.001)$ were also significantly higher in formula-fed than in breast-fed infants, with significant differences seen throughout the first year of life (Fig. 2). A contrary situation was evident with TGF- $\beta 2$. The concentrations of TGF- $\beta 2(P \leq 0 \cdot 0001)$ were significantly lower in formula-fed than in breast-fed infants throughout the first year of life, with up to ten-fold differences seen (Fig. 3).

No statistically significant differences were evident between the serum concentrations of interferon $\gamma(P=0 \cdot 10)$, IL-10 $(P=0 \cdot 05), \operatorname{IL}-5(P=0 \cdot 84)$ or IL-4 $(P=0 \cdot 28)$ (Table 2$)$

\section{Differing numbers of Ig-secreting cells in formula-fed and breast-fed infants}

The different levels of cows' milk antigen exposure between the two study groups were well-reflected in the

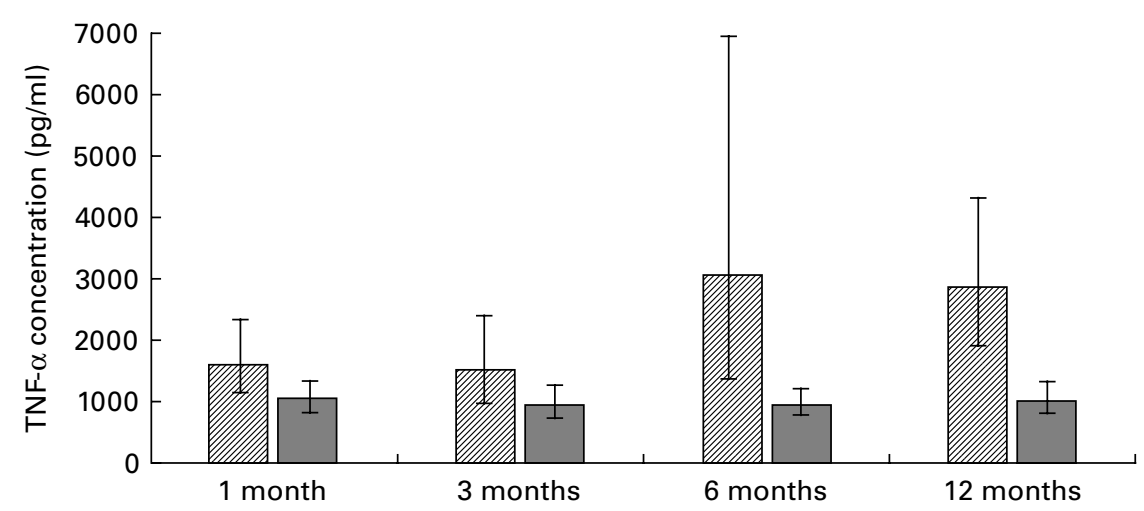

Fig. 1. Serum TNF- $\alpha$ concentrations in formula-fed $(\mathbb{Z})$ and breast-fed infants $(\square)$. ANOVA for repeated measures showed a significant difference in TNF- $\alpha$ concentrations $(P=0.0019)$. Statistically significant differences were evident for 1 month $(P=0.039), 3$ months $(P=0.010), 6$ months $(P<0.0011)$ and 12 months $(P=0.039)$. 


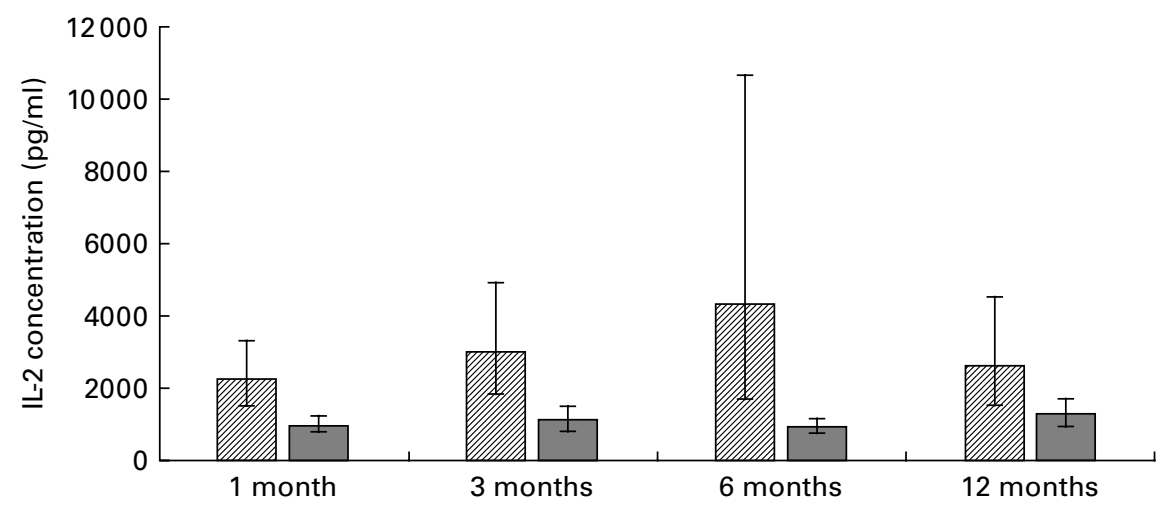

Fig. 2. Serum IL-2 concentrations in formula-fed (国) and breast-fed infants ( $\square$ ). ANOVA for repeated measures showed a significant difference in IL-2 concentrations $(P \leq 0.001)$. Statistically significant differences were evident for 1 month $(P=0.0003), 3$ months $(P=0.001), 6$ months $(P=0.0001)$ and 12 months $(P \leq 0.014)$.

enzyme-linked immunospot assay results for casein-specific Ig. The numbers of casein-specific IgA- and IgG-secreting cells were significantly greater in formula-fed than in breastfed children at 3 and 6 months of age, but not at a later age (Table 3). In the infants receiving formula, the highest numbers of casein-specific Ig-secreting cells were seen at 3 months, and the total number of secreting cells decreased with age. The opposite was true in the breast-fed group, where low amounts of casein-specific Ig-secreting cells were seen at 3 months, and the number of total secreting cells increased with age so that by age 12 months, no significant difference remained between the groups.

\section{Discussion}

The gold standard and optimum goal of early infant nutrition should be the healthy, breast-fed infant. Defining correct nutrition by detailing the precise composition of what the infant feeds on is an approach that is prone to erroneous conclusions. The composition of breast milk varies from one individual to another, and can also change in each lactating woman due to diet, parity, season and stage of lactation. The biologically active components of breast milk are diverse and show even more variation than the nutritive components.
The dynamics of how cytokines and other biologically active breast milk components affect each individual infant are impossible to predict. Thus, we must study and compare the physiology, in the case of the present study, the immune physiology of infants under different modes of feeding in order to assess the nutritive and physiological appropriateness of each diet.

One of the most striking differences between breast-fed and formula-fed infants was evident in the serum concentrations of the TGF- $\beta$ isoform, TGF- $\beta 2$, with breast-fed infants exhibiting significantly higher levels of this anti-inflammatory cytokine. TGF- $\beta 2$ has a wide variety of effects extending from regulation of cell proliferation and differentiation to modulation of immune responses ${ }^{(32-35)}$. It also appears to contribute to mucosal barrier function by inducing IgA production $^{(36)}$. Several studies have indicated the importance of TGF- $\beta 2$ in the process of tolerisation ${ }^{(37,38)}$. Higher serum concentrations of the potentially pro-inflammatory cytokines TNF- $\alpha$ and IL- 2 were seen in formula-fed than in breast-fed infants. TNF- $\alpha$ is a pleiotropic cytokine with wide-ranging pro-inflammatory effects, and its ability to disrupt mucosal barrier function is well-acknowledged ${ }^{(39,40)}$. Elevated concentrations of TNF- $\alpha$ prevailed in formula-fed infants throughout the first year of life. The present results thus suggest that early

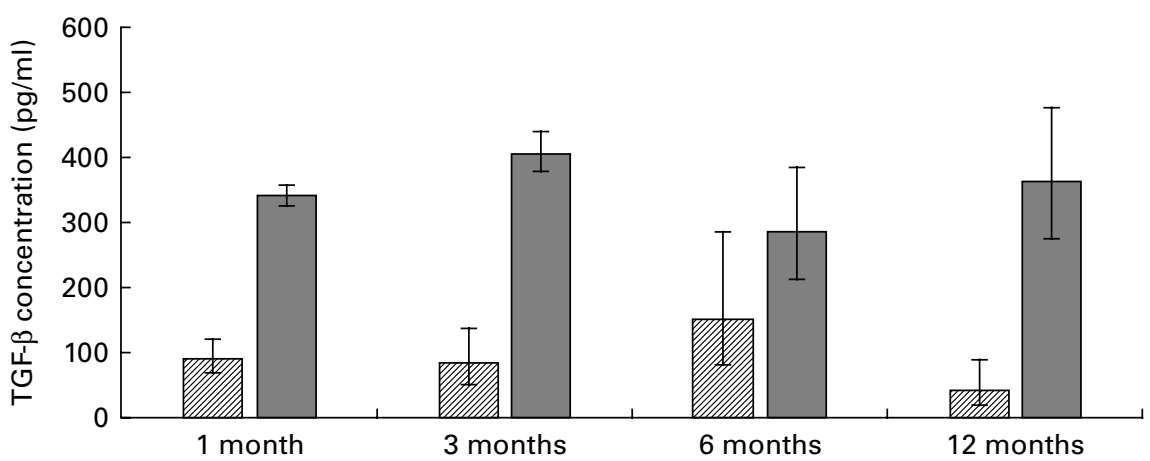

Fig. 3. Serum transforming growth factor $\beta 2$ (TGF- $\beta 2$ ) concentrations in formula-fed (ש) and breast-fed infants ( $\square$ ). ANOVA for repeated measures showed a significant difference in TGF- $\beta 2$ concentrations $(P \leq 0.0001)$. Statistically significant differences were evident for 1 month $(P \leq 0.0001)$, 3 months $(P \leq 0.0001)$, 6 months $(P=0.039)$ and 12 months $(P \leq 0.0001)$. 
Table 3. Numbers of Ig-secreting (Ig-scr.) cells in formula-fed and breast-fed infants (enzyme-linked immunospot assay) (Geometric means and 95\% confidence intervals)

\begin{tabular}{|c|c|c|c|c|c|c|c|c|c|c|c|c|c|}
\hline & \multirow[b]{3}{*}{$\begin{array}{c}\text { Age } \\
\text { (months) }\end{array}$} & \multicolumn{4}{|c|}{ All participants } & \multirow{3}{*}{$\begin{array}{c}P \\
\text { (ANOVA } \\
\text { for } \\
\text { repeated } \\
\text { measures) }\end{array}$} & \multirow[b]{3}{*}{$P$} & \multicolumn{4}{|c|}{ Only atopic mothers } & \multirow{3}{*}{$\begin{array}{c}P \\
\text { (ANOVA } \\
\text { for } \\
\text { repeated } \\
\text { measures) }\end{array}$} & \multirow[b]{3}{*}{$P$} \\
\hline & & \multicolumn{2}{|c|}{ Formula-fed ( $n$ 18) } & \multicolumn{2}{|c|}{ Breast-fed ( $n$ 29) } & & & \multicolumn{2}{|c|}{ Formula-fed ( $n$ 12) } & \multicolumn{2}{|c|}{ Breast-fed ( $n$ 29) } & & \\
\hline & & $\begin{array}{c}\text { Geometric } \\
\text { mean }\end{array}$ & $95 \% \mathrm{Cl}$ & $\begin{array}{l}\text { Geometric } \\
\text { mean }\end{array}$ & $95 \% \mathrm{Cl}$ & & & $\begin{array}{l}\text { Geometric } \\
\text { mean }\end{array}$ & $95 \% \mathrm{Cl}$ & $\begin{array}{c}\text { Geometric } \\
\text { mean }\end{array}$ & $95 \% \mathrm{Cl}$ & & \\
\hline \multirow{3}{*}{$\begin{array}{l}\text { Total lg-scr. } \\
\text { cells } / 10^{6} \text { cells }\end{array}$} & 3 & 1425 & 1079,1883 & 1329 & 1048,1684 & 0.18 & & 1628 & 1102,2405 & 1329 & 1048,1684 & 0.34 & \\
\hline & 6 & 1873 & 1400,2564 & 1782 & 1330,2388 & & & 1542 & 1121,2121 & 1782 & 1330,2388 & & \\
\hline & 12 & 2320 & 1604,3354 & 2352 & 1635,3383 & & & 2267 & 1472,3491 & 2352 & 1635,3383 & & \\
\hline \multirow{3}{*}{$\begin{array}{l}\text { Total Ig-scr. } \\
\text { cells } / 10^{4} \text { cells }\end{array}$} & 3 & 1402 & 1114,1765 & 1359 & 1051,1757 & 0.77 & & 1513 & 1092, 2098 & 1359 & 1051,1757 & 0.52 & \\
\hline & 6 & 1748 & 1192, 2564 & 1734 & 1223,2460 & & & 1191 & 884,1604 & 1734 & 1223,2460 & & \\
\hline & 12 & 2417 & 1692, 3452 & 1981 & 1385,2833 & & & 2339 & 1592,3436 & 1981 & 1385,2833 & & \\
\hline \multirow{3}{*}{$\begin{array}{l}\text { Total IgM-scr. } \\
\text { cells } / 10^{6} \text { cells }\end{array}$} & 3 & 610 & 458,796 & 422 & 332,600 & 0.63 & & 707 & 483,1032 & 422 & 332,600 & 0.98 & \\
\hline & 6 & 743 & 464,1189 & 693 & 519,868 & & & 533 & 300,948 & 693 & 519,868 & & \\
\hline & 12 & 971 & 586,1611 & 1166 & 763,1781 & & & 786 & 450,1374 & 1166 & 763,1781 & & \\
\hline Casein-specific & 3 & $3 \cdot 2$ & $1 \cdot 8,5 \cdot 7$ & 1 & $0 \cdot 8,1 \cdot 3$ & 0.0005 & 0.0004 & $2 \cdot 6$ & $1 \cdot 2,5 \cdot 4$ & 1 & $0 \cdot 8,1 \cdot 3$ & 0.01 & 0.008 \\
\hline IgA-scr. & 6 & 2.5 & $1.4,4.4$ & $1 \cdot 1$ & $0.8,1.5$ & & 0.015 & $2 \cdot 4$ & $1 \cdot 2,4 \cdot 9$ & 1.1 & $0.8,1.5$ & & 0.041 \\
\hline cells $/ 10^{6}$ cells & 12 & $2 \cdot 3$ & $1.4,3.8$ & 1.3 & $0.9,1.9$ & & 0.1 & $2 \cdot 2$ & $1 \cdot 2,4 \cdot 1$ & 1.3 & $0.9,1.9$ & & 0.19 \\
\hline Casein-specific & 3 & 5.4 & $3 \cdot 1,9.4$ & 0.9 & $0 \cdot 8,1 \cdot 0$ & $<0.0001$ & $<0.0001$ & 5.5 & $3 \cdot 0,10 \cdot 0$ & 0.9 & $0 \cdot 8,1 \cdot 0$ & $<0.0001$ & $<0.0001$ \\
\hline IgG-scr. & 6 & $3 \cdot 3$ & $1 \cdot 8,6 \cdot 1$ & 1.1 & $0.8,1 \cdot 4$ & & 0.001 & $4 \cdot 3$ & $2 \cdot 1,8 \cdot 7$ & 1.1 & $0.8,1.4$ & & 0.0002 \\
\hline cells $/ 10^{6}$ cells & 12 & $2 \cdot 6$ & $1 \cdot 3,5 \cdot 2$ & 1.5 & $1 \cdot 0,2 \cdot 2$ & & $0 \cdot 17$ & $2 \cdot 2$ & $1 \cdot 0,4 \cdot 6$ & 1.5 & $1 \cdot 0,2 \cdot 2$ & & 0.39 \\
\hline Casein-specific & 3 & $4 \cdot 1$ & $2 \cdot 4,7 \cdot 0$ & 1.9 & $1 \cdot 1,3 \cdot 1$ & 0.24 & & 4.9 & $2 \cdot 4,9 \cdot 8$ & 1.9 & $1 \cdot 1,3 \cdot 1$ & 0.38 & \\
\hline IgM-scr. & 6 & 3.3 & $1.5,7.5$ & $2 \cdot 2$ & $1.5,3.4$ & & & $3 \cdot 3$ & $1 \cdot 1,6 \cdot 1$ & $2 \cdot 2$ & $1.5,3.4$ & & \\
\hline cells $/ 10^{6}$ cells & 12 & 2.9 & $1 \cdot 3,6 \cdot 6$ & $2 \cdot 6$ & $1 \cdot 5,4 \cdot 6$ & & & $2 \cdot 2$ & $1 \cdot 0,4 \cdot 9$ & $2 \cdot 6$ & $1 \cdot 5,4 \cdot 6$ & & \\
\hline
\end{tabular}


consumption of formula is associated with pro-inflammatory immune responsiveness during the first year of life. In contrast, exclusive breast-feeding promotes an anti-inflammatory cytokine milieu, which is maintained throughout infancy.

There are several possible explanatory models for the observed results. We propose it is likely that the differences seen between breast-fed and formula-fed infants could be due to direct immunoregulatory effects of breast milk TGF- $\beta 2$, the effects of breast-feeding on infant gut microbiota, functional immune cells and other immunoactive substances contained in breast milk.

It is likely that breast-fed infants have ingested more exogenic TGF- $\beta 2$ than the infants fed with formula. In a mouse model, enterally given TGF- $\beta$ emerged as systemic, immunologically active TGF- $\beta$ in nursing mouse pups ${ }^{(41)}$. In another animal experiment, enterally given TGF- $\beta$ was shown to induce endogenous TGF- $\beta$ production ${ }^{(42)}$. We, and others, have shown in previous studies that the concentrations of breast milk cytokines not only mirror the clinical immunological status of the mother, but are also reflected in the cytokine concentrations and clinical manifestations of their child ${ }^{(43-45)}$. For example, high breast milk TGF- $\beta 2$ concentrations are associates with reduced risk of atopic disease in the infant ${ }^{(46)}$. Serum cytokine levels not only reflect the present state of immune activity, but also have the potential to guide the development and polarisation process of various immune cells, yielding long-lasting, perhaps even permanent, effects on the individual's immune function.

Indeed, the elevated serum TGF- $\beta 2$ in breast-fed infants was seen to persist throughout the first year of life, despite reversion to a similar diet as the formula-fed group due to the consumption of solid foods and cows' milk, as well as the cessation of breast-feeding. In light of the present finding, it seems that the consumption of breast milk may not only have direct immunoregulatory effects, but also the potential to guide the infant's own immune system towards the production of regulatory $\mathrm{T}$ cells and healthy immune function.

The persistent anti-inflammatory effects of breast-feeding may also be due to the effects of breast milk on infant gut microbiota. In addition to active microbes ${ }^{(47-49)}$ and molecules operative in microbial recognition ${ }^{(50)}$, breast milk contains an abundance of complex oligosaccharides that the microbial populations in the developing intestine utilise ${ }^{(51-53)}$. These oligosaccharides are believed to facilitate development of a healthy, infant intestinal microbiota rich in bifidobacteria. Recent genomic analyses suggest an intricate co-evolution among the human host, milk glycans and the microbes they enrich, as human milk oligosaccharides appear to very specifically favour colonisation with certain microbial species that have previously been shown to be beneficial to health ${ }^{(54)}$, further underlining the unique role of breast milk in the immunological education of the neonate.

The present results showed a similar phenomenon regarding casein-specific Ig-secreting cells, as others focusing on antibody levels have done previously ${ }^{(55-58)}$. The higher levels witnessed in formula-fed infants may simply be a reflection of the higher antigen exposure that the formula-fed infants are subjected to, and, consequently, antibody levels in themselves should not be regarded as an indication of permanently altered immune development. The witnessed enzyme-linked immunospot assay results validate the present study group division and show that formula-fed infants are exposed to foreign antigens at an earlier age and to a greater extent than breast-fed infants. This phenomenon in itself could also contribute to the immunological differences witnessed between the groups, but conclusions on causality cannot be drawn from the present study. It is interesting to note that differences in serum cytokine concentrations outlast the differences witnessed in the numbers of cows' milk-specific Ig-secreting cells, again suggesting a type of immune programming by breast milk.

The breast-fed infants in the present study manifested high levels of TGF- $\beta 2$ and low levels of pro-inflammatory cytokines throughout the first year of life and exceeding the duration of breast-feeding. Such an immunological environment limits IgE production and hyper-responsiveness and promotes tolerisation, possibly prohibiting the onset of allergic disease. In the pursuit for improved forms of alternative infant nutrition, manufacturers should not necessarily solely endeavour to mimic the composition of breast milk, but rather aim to achieve similar physiological effects in the infant.

\section{Acknowledgements}

We would like to thank Mika Korkeamäki and Heikki Arvilommi for their contributions towards the present study. Funding for the present study was received from the Academy of Finland and the Finnish Cultural Foundation VarsinaisSuomi regional fund. The authors are not aware of any conflict of interest. All authors contributed intellectually to the manuscript to the extent that they can defend the contents.

\section{References}

1. Newburg DS \& Walker WA (2007) Protection of the neonate by the innate immune system of developing gut and of human milk. Pediatr Res 61, 2-8.

2. Lonnerdal B (2003) Nutritional and physiologic significance of human milk proteins. Am J Clin Nutr 77, 1537S-1543S.

3. Jeliffe DB \& Jeliffe EF (1981) Breast milk and infection. Lancet ii, 419 .

4. Ruiz-Palacios GM, Calva JJ, Pickering LK, et al. (1990) Protection of breast-fed infants against Campylobacter diarrbea by antibodies in human milk. $J$ Pediatr 116, 707-713.

5. Clavano NR (1982) Mode of feeding and its effect on infant mortality and morbidity. J Trop Pediatr 28, 287-293.

6. Arifeen S, Black RE, Antelman G, et al. (2001) Exclusive breast-feeding reduces acute respiratory infection and diarrhea deaths among infants in Dhaka slums. Pediatrics 108, E67.

7. Wilson AC, Forsyth JS, Greene SA, et al. (1998) Relation of infant diet to childhood health: seven year follow up of cohort of children in Dundee infant feeding study. BMJ 316, 21-25.

8. Duncan B, Ey J, Halberg CJ, et al. (1994) Exclusive breast feeding for at least 4 months protects against otitis media. Pediatrics 91, 867-872. 
9. Golding J, Emmett PM \& Rogers IS (1997) Does breast feeding protect against non-gastric infections? Early Hum Dev 29, S105-S120.

10. Kramer MS, Chalmers B, Hodnett ED, et al. (2001) Promotion of Breast-feeding Intervention Trial (PROBIT): a randomized trial in the Republic of Belarus. JAMA 285, 413-420.

11. Rosenbauer J, Herzig P \& Giani G (2008) Early infant feeding and risk of type 1 diabetes mellitus - a nationwide population-based case-control study in pre-school children. Diabetes Metab Res Rev 24, 211-222.

12. Barclay AR, Russell RK, Wilson ML, et al. (2009) Systematic review: the role of breast-feeding in the development of pediatric inflammatory bowel disease. $J$ Pediatr 155 , 421-426.

13. Akobeng AK, Ramanan AV, Buchan I, et al. (2006) Effect of breast feeding on risk of coeliac disease: a systematic review and meta-analysis of observational studies. Arch Dis Child 91, 39-43.

14. Lucas A, Brooke OG, Morley R, et al. (1990) Early diet in preterm infants and development of allergic or atopic disease: randomized prospective study. BMJ 300, 837-840.

15. Kull I, Wickman M, Lilja G, et al. (2002) Breast-feeding and allergic diseases in infants - a prospective birth study cohort. Arch Dis Child 87, 478-481.

16. Kull I, Almqvist C, Lilja G, et al. (2004) Breast-feeding reduces the risk of asthma during the first 4 years of life. J Allergy Clin Immunol 114, 755-760.

17. Oddy WH, Sly PD, de Klerk NH, et al. (2003) Breast feeding and respiratory morbidity in infancy: a birth cohort study. Arch Dis Child 88, 224-228.

18. Kerkhof M, Koopman LP, van Strien RT, et al. (2003) Risk factors for atopic dermatitis in infants at high risk of allergy: the PIAMA study. Clin Exp Allergy 33, 1336-1341.

19. Lauberau B, Brockow I, Zirngibl A, et al. (2004) Effects of breast-feeding on the development of atopic dermatitis during the first 3 years of life.-results from the GINI-birth cohort study. J Pediatr 144, 602-607.

20. Chandra RK, Puri S \& Cheema PS (1985) Predictive value of cord blood IgE in the development of atopic disease and role of breast-feeding in its prevention. Clin Allergy 15, 517-522.

21. Vandenplas Y, Deneyr M, Sacre L, et al. (1988) Preliminary data on a field study with a new hypo-allergenic formula. Eur J Pediatr 148, 274-277.

22. Rautava S \& Walker WA (2009) Academy of Breast-feeding Medicine founder's lecture 2008: breast-feeding - an extrauterine link between mother and child. Breastfeed Med $\mathbf{4}$, $3-10$.

23. Liepke C, Adermann K, Raida M, et al. (2002) Human milk provides peptides highly stimulating the growth of bifidobacteria. Eur J Biochem 269, 712-718.

24. Harmsen HJ, Wildeboer-Veloo AC, Raangs GC, et al. (2000) Analysis of intestinal flora development in breast-fed and formula-fed infants by using molecular identification and detection methods. J Pediatr Gastroenterol Nutr 30, 61-67.

25. Friedman NJ \& Zeiger RS (2005) The role of breast-feeding in the development of allergies and asthma. J Allergy Clin Immunol 115, 1238-1248.

26. Sears MR, Greene JM, Willan AR, et al. (2002) Long-term relation between breast-feeding and development of atopy and asthma in children and young adults: a longitudinal study. Lancet 360, 901-907.

27. Miyake Y, Yura A \& Iki M (2003) Breast-feeding and the prevalence of symptoms of allergic disorders in Japanese adolescents. Clin Exp Allergy 33, 312-316.
28. Bergmann RL, Diepgen TL, Kuss O, et al. (2002) Breastfeeding duration is a risk factor for atopic eczema. Clin Exp Allergy 32, 205-209.

29. Taylor B, Wadsworth J, Golding J, et al. (1983) Breastfeeding, eczema, asthma and hayfever. J Epidemiol Community Health 37, 95-99.

30. Kaplan BA \& Mascie-Taylor CG (1985) Biosocial factors in the epidemiology of childhood asthma in a British national sample. J Epidemiol Community Health 39, 152-156.

31. Rusconi F, Galassi C, Corbo GM, et al. (1999) Risk factors for early, persistent and late onset wheezing in young children. SIDRIA Collaborative Group. Am J Respir Crit Care Med 160, 1617-1622.

32. Li MO, Wan YY, Sanjabi S, et al. (2006) Transforming growth factor-beta regulation of immune responses. Annu Rev Immunol 24, 99-146.

33. Ludviksson BR, Seegers D, Resnick AS, et al. (2000) The effect of TGF-beta1 on immune responses of naive versus memory $\mathrm{CD}^{+}$Th1/Th2 T cells. Eur J Immunol 30 2101-2111.

34. Takeuchi M, Alard P \& Streilein JW (1998) TGF-beta promotes immune deviation by altering accessory signals of antigen-presenting cells. J Immunol 160, 1589-1597.

35. Nakamura K, Kitani A, Fuss I, et al. (2004) TGF-beta 1 plays an important role in the mechanism of $\mathrm{CD} 4{ }^{+} \mathrm{CD} 25^{+}$regulatory $\mathrm{T}$ cell activity in both humans and mice. J Immunol 172, 834-842.

36. Ogawa J, Sasahara A, Yoshida T, et al. (2004) Role of transforming growth factor-beta in breast milk for initiation of IgA production in newborn infants. Early Hum Dev $\mathbf{7 7}$, 67-75.

37. Verhasselt V, Milcent V, Cazareth J, et al. (2008) Breast milk-mediated transfer of an antigen induces tolerance and protection from allergic asthma. Nat Med 14, 170-175.

38. Penttila I (2006) Effects of transforming growth factor-beta and formula feeding on systemic immune responses to dietary beta-lactoglobulin in allergy-prone rats. Pediatr Res 59, $650-655$

39. Sanders DS (2005) Mucosal integrity and barrier function in the pathogenesis of early lesions in Crohn's disease. $J$ Clin Pathol 58, 568-572.

40. Desjeux JF \& Heyman M (1994) Milk proteins, cytokines and intestinal epithelial functions in children. Acta Paediatr Jpn 36, 592-596.

41. Letterio JJ, Geiser AG, Kulkarni AB, et al. (1994) Maternal rescue of transforming growth factor-beta 1 null mice. Science 264, 1936-1938.

42. Ando T, Hatsushika K, Wako M, et al. (2007) Orally administered TGF-beta is biologically active in the intestinal mucosa and enhances oral tolerance. J Allergy Clin Immunol 120, 916-923.

43. Jones CA, Holloway JA, Popplewell EJ, et al. (2002) Reduced soluble CD14 levels in amniotic fluid and breast milk are associated with the subsequent development of atopy, eczema, or both. J Allergy Clin Immunol 109, 858-866.

44. Laiho K, Lampi AM, Hamalainen M, et al. (2003) Breast milk fatty acids, eicosanoids, and cytokines in mothers with and without allergic disease. Pediatr Res 53, 642-647.

45. Hoppu U, Kalliomaki M, Laiho K, et al. (2001) Breast milkimmunomodulatory signals against allergic diseases. Allergy 56, 23-26.

46. Kalliomaki M, Ouwehand A, Arvilommi H, et al. (1999) Transforming growth factor-beta in breast milk: a potential regulator of atopic disease at an early age. Allergy Clin Immunol 104, 1251-1257. 
47. Gueimonde M, Laitinen K, Salminen S, et al. (2007) Breast milk: a source of bifidobacteria for infant gut development and maturation? Neonatology 92, 64-66.

48. Donnet-Hughes A, Perez PF, Doré J, et al. (2010) Potential role of the intestinal microbiota of the mother in neonatal immune education. Proc Nutr Soc 69, 407-415.

49. Abrahamsson TR, Sinkiewicz G, Jakobsson T, et al. (2009) Probiotic lactobacilli in breast milk and infant stool in relation to oral intake during the first year of life. J Pediatr Gastroenterol Nutr 49, 349-354.

50. LeBouder E, Rey-Nores JE, Raby AC, et al. (2006) Modulation of neonatal microbial recognition: TLR-mediated innate immune responses are specifically and differentially modulated by human milk. J Immunol 176, 3742-3752.

51. Chichlowski M, German JB, Lebrilla CB, et al. (2011) The influence of milk oligosaccharides on microbiota of infants: opportunities for formulas. Annu Rev Food Sci Technol 2 331-351.

52. Bakker-Zierikzee AM, Alles MS, Knol J, et al. (2005) Effects of infant formula containing a mixture of galacto- and fructooligosaccharides or viable Bifidobacterium animalis on the intestinal microflora during the first 4 months of life. $\mathrm{Br} \mathrm{J}$ Nutr 94, 783-790.

53. Asakuma S, Hatakeyama E, Urashima T, et al. (2011) Physiology of consumption of human milk oligosaccharides by infant gut-associated bifidobacteria. I Biol Chem $\mathbf{2 8 6}$, 34583-34592.

54. Sela DA, Chapman J, Adeuya A, et al. (2008) The genome sequence of Bifidobacterium longum subsp. infantis reveals adaptations for milk utilization within the infant microbiome. Proc Natl Acad Sci U S A $\mathbf{1 0 5}$, 18964-18969.

55. Kaila M, Arvilommi H, Soppi E, et al. (1994) A prospective study of humoral immune responses to cow milk antigens in the first years of life. Pediatr Allergy Immunol 5, 164-169.

56. Tainio VM, Savilahti E, Arjomaa P, et al. (1988) Plasma antibodies to cow's milk are increased by early weaning and consumption of unmodified milk, but production of plasma IgA and IgM cow's milk antibodies is stimulated even during exclusive breast-feeding. Acta Paediatr Scand 77, 807-811.

57. Vaarala O, Saukkonen T, Savilahti E, et al. (1995) Development of immune response to cow's milk proteins in infants receiving cow's milk or hydrolysed formula. J Allergy Clin Immunol 96, 917-923.

58. Jenmalm MC \& Björksten B (1998) Exposure to cow's milk during the first 3 months of life is associated with increased levels of IgG antibodies to beta-lactoglobulin up to 8 years. J Allergy Clin Immunol 102, 671-678. 